\title{
Prevalence and Risk Factors associated with Impaired Fasting Glucose in Adults from Maracaibo City, Venezuela
}

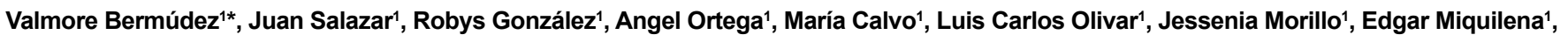
Mervin Chávez-Castillo ${ }^{1}$, Rendy Chaparro ${ }^{1}$, Mayela Cabrera ${ }^{1}$ and Joselyn Rojas ${ }^{1,2}$

${ }^{1}$ Endocrine and Metabolic Diseases Research Center, University of Zulia, Maracaibo, Venezuela

${ }^{2}$ Division of Pulmonary and Critical Care Medicine, Brigham and Women's Hospital and Harvard Medical School, Boston, MA. 02115, USA

\begin{abstract}
Objective: The purpose of this study was to evaluate the prevalence and risk factors associated with impaired fasting glucose (IFG) in adult individuals from Maracaibo city, Venezuela.

Materials and methods: 2230 patients from the Maracaibo Metabolic Syndrome Prevalence Study were selected. IFG was defined according to the 2016 ADA criteria. A multiple logistic regression model was constructed in order to assess risk factors associated with IFG.

Results: In the general population, the prevalence of IFG was $19.5 \%(n=435)$, with $46.4 \%(n=202)$ being women and $53.6 \%(n=233)$ being men, $p=0.004$. The main risk factors associated with IFG were age $(\geq 60$ years: OR=2.31; $\mathrm{Cl}$ $95 \%=1.23-4.35 ; p<0.01$ ), alcohol consumption, abdominal obesity and insulin resistance. After evaluating individuals with IFG exclusively, the major risk factor was the presence of elevated high-sensitivity C-Reactive Protein levels $(\mathrm{OR}=2.03 ; \mathrm{Cl} 95 \%=1.13-3.67 ; \mathrm{p}<0.02)$.

Conclusions: In Maracaibo the prevalence of IFG is similar to that of international reports. It is associated with a variety of risk factors, especially abdominal obesity, insulin resistance and low-grade inflammation, demonstrating the close link between adiposopathy and alterations in glucose metabolism.
\end{abstract}

Keywords: Impaired fasting glucose; Insulin resistance; Obesity; Physical activity; Hypertension; Inflammation; Diabetes

\section{Introduction}

Type 2 Diabetes Mellitus (T2D) is responsible for approximately 4.9 deaths a year worldwide, with a projected $59 \%$ increase in these estimates by year 2035 [1]. In 2003, the American Diabetes Association (ADA) recognized an intermediate metabolic stage in which blood glucose levels are higher than normal range but do not reach the diagnostic criteria for T2D, leading to the birth of the concepts of impaired fasting glucose (IFG) and impaired glucose tolerance (IGT) [2]; often grouped together and termed "Pre-Diabetes" [3]. Recently, the prevalence of this metabolic alteration in American adults was found to be $37 \%$ in the general population, and $51 \%$ in subjects older than 65 years of age [4]. In subjects classified as pre-diabetics, IFG appears to be twice as frequent as IGT [5], representing an important risk factor for T2D [6].

The pathophysiology of IFG has been described to involve hepatic insulin resistance and a deficient early phase insulin secretion [7]. Therefore, IFG is often associated with overweight and obesity, both common in populations with deleterious habits and risk factors such as physical inactivity, high-calorie diets, excessive alcohol consumption and smoking [8]; all of which contribute to progressive dysfunction of pancreatic beta cells, a mechanism shared with $\mathrm{T} 2 \mathrm{D}$, but present in a less severe form in IFG [9].

Identification of patients with IFG is clinically relevant, considering that changes in lifestyle and potential pharmacological intervention could reduce the risk of advancing into T2D and favor regression to euglycemia $[10,11]$. In view of the scarcity of reports on the epidemiological behavior of this metabolic disorder in our locality, the purpose of this study was to evaluate the prevalence and risk factors associated with impaired fasting glucose (IFG) in adult individuals from the Maracaibo city, Venezuela.

\section{Materials and Methods}

\section{Subjects selection}

The sample method has been already published in the Maracaibo City Metabolic Syndrome Prevalence Study cross-sectional proposal [12], yet the main aspects will be mentioned. This was a cross-sectional, descriptive, randomized, multistage study which enrolled a total of 2,230 subjects. The study was approved by the Bioethics Committee of the Endocrine and Metabolic Diseases Research Center - University of Zulia, and all participants signed a written consent before being interrogated and physically examined by a trained team.

\section{Subjects evaluation}

Data were collected through completion of a full clinical record carried out by trained personnel, who encompassed interrogation on personal and family history of endocrine and cardiovascular disease, and determination of socioeconomic status by the Graffar scale modified by Méndez-Castellano [13].

Based on information obtained during the clinical interview, subjects were categorized by their smoking habits as follows [14]: a)

*Corresponding author: Valmore Bermúdez, University of Zulia, Endocrine and Metabolic Diseases Research Center "Dr. Félix Gómez" Av. 20, Maracaibo 4004 Venezuela, Tel: +582617597279; E-mail: valmore@gmail.com

Received April 25, 2016; Accepted June 29, 2016; Published June 30, 2016

Citation: Bermúdez V, Salazar J, González R, Ortega A, Calvo M, et al. (2016) Prevalence and Risk Factors associated with Impaired Fasting Glucose in Adults from Maracaibo City, Venezuela. J Diabetes Metab 7: 683. doi:10.4172/2155 6156.1000683

Copyright: @ 2016 Bermúdez V, et al. This is an open-access article distributed under the terms of the Creative Commons Attribution License, which permits unrestricted use, distribution, and reproduction in any medium, provided the original author and source are credited. 
Non-Smokers, individuals who had never smoked, or had smoked $<100$ cigarettes in their lifetime; b) Current Smokers, subjects who had smoked $\geq 100$ cigarettes in their lifetime, or reported current habitual smoking at the time of evaluation, or had quit smoking less than one year prior to our assessment; and c) Past Smokers, individuals who had consumed $\geq 100$ cigarettes in their lifetime and quit over one year prior to our questioning. Regarding alcohol intake, drinkers were defined as subjects who consumed $\geq 1$ gram of alcohol daily [15].

Physical activity (PA) was assessed with the International Physical Activity Questionnaire (IPAQ) [16]. For statistical analysis, PA was evaluated in 4 domains: Occupational, Household, Transport and Leisure. In each of these domains, subjects were categorized as: a) Inactive, MET/week=0; or b) Active, MET/week $>0$. The latter were then subcategorized by gender-specific MET/week quintiles in each domain.

\section{Clinical evaluation}

Blood pressure (BP) was taken with subjects sitting down with their feet on the floor following 15 minutes of rest, determined through the auscultatory method with a calibrated mercury sphygmomanometer; identifying Korotkoff's phases I and V as systolic and diastolic BP respectively. BP was determined 3 times, with 15 minutes in between each take, on two different days; results were classified by the Eighth Joint National Committee on Prevention, Detection, Evaluation, and Treatment of High Blood Pressure (JNC-8) guidelines [17].

An electrical bioelectric scale was used to obtain weight (Tanita, TBF-310 GS Body Composition Analyzer, Tokyo - Japan). Height was measured using a calibrated metric measurement tape, with the subject standing up barefoot. Body Mass Index (BMI) was calculated with the formula: [weight/height2] expressing results as $\mathrm{kg} / \mathrm{m}^{2}$. According to their BMI, subjects were sorted in 3 categories: a) BMI $\leq 24.9$; b) 2529.9; and c) $\geq 30$ [18]. Waist circumference (WC) was evaluated with calibrated measuring tapes in accordance to the anatomical landmarks proposed by the USA National Institutes of Health protocol [19].

\section{Laboratory analysis}

Overnight fasting determination of glucose, total cholesterol, triacylglycerides (TAG), and HDL-C was done with an automated analyzer (Human Gesellschaft für Biochemica und Diagnostica mbH, Germany); the intra-assay variation coefficients for total cholesterol, TAG, and HDL-C were $3 \%, 5 \%$, and $5 \%$, respectively. LDL-C and VLDL-C levels were calculated applying Friedewald's formula [20] but when TAG levels were $<400 \mathrm{mg} / \mathrm{dL}$. LDL-C concentrations were directly measured through lipoprotein electrophoresis and densitometry with a BioRad GS-800 optical densitometer. Insulin was quantified using ultrasensitive ELISA double-sandwich methodology (DRG Instruments $\mathrm{GmbH}$, Germany, Inc.). Serum high-sensitivity C-Reactive Protein (hsCRP) was quantified through immunoturbidimetric assays (Human Gesellschaft fur"Biochemica und Diagnostica mbH, Germany).

\section{Definitions}

Subjects having the following characteristics were operatively classified as having T2D: a) Those with a previously established diagnosis of T2D; and $\mathrm{b}$ ) Those without personal history of T2D but with fasting glucose $\geq 126 \mathrm{mg} / \mathrm{dL}$ (2). On the other hand, non-diabetic subjects were classified as follows: a) normoglycemic (NG), individuals with fasting glucose $<100 \mathrm{mg} / \mathrm{dL}$; and b) Impaired Fasting Glucose (IFG) those fasting glycemia $100-126 \mathrm{mg} / \mathrm{dL}$ [21].

As per the IDF/NHLBI/AHA/WHF/IAS/IASO-2009 consensus criteria [22], abdominal obesity was defined as waist circumference $\geq 80 \mathrm{~cm}$ in females or $\geq 90 \mathrm{~cm}$ in males. Likewise, we use local waist circumference cutoff points $\geq 90 \mathrm{~cm}$ (females) and $\geq 95 \mathrm{~cm}$ (males) in abdominal obesity definition [23].

Regarding a lipid definition, hypertriacylglyceridemia was defined as fasting TAG $\geq 150 \mathrm{mg} / \mathrm{dL}$; and low HDL-C as fasting HDL-C $<50 \mathrm{mg} /$ $\mathrm{dL}$ in females or $<40 \mathrm{mg} / \mathrm{dL}$ in males. HOMA2-IR was utilized for the evaluation of insulin resistance (IR) as proposed by Levy et al. computed with the HOMA-Calculator v2.2.2 software application, IR was defined as HOMA2-IR $\geq 2$ [24] and elevated hs-CRP was defined as levels $\geq 0.765 \mathrm{mg} / \mathrm{L}$ [25].

\section{Statistical Analysis}

Qualitative variables were expressed as absolute and relative frequencies, evaluating association through Pearson's Chi-squared $\left(\chi^{2}\right)$ test. Quantitative variables were evaluated for distribution normality with Geary's test and were expressed as arithmetic means \pm SD. Variables with non-normal distribution underwent logarithmic transformation; when normalization could not be achieved (TAG, HDL-C hs-CRP), these variables were expressed as medians (25th percentile-75th percentile). One-Way ANOVA or Kruskal-Wallis tests were applied to evaluate differences between means or medians, respectively.

A multiple logistic regression model was constructed in order to estimate odds ratios (Confidence Interval 95\%) for the presence of IFG, adjusted by gender, age groups, ethnic groups, socioeconomic status, educational status, marital status, occupational status, smoking habits, leisure-domain PA, presence of high TAG, presence of low HDL-C, JNC-8 classification, presence of elevated WC, BMI classification, presence of elevated hs-CRP and presence of IR. A second model was constructed, introducing adjustment for presence of elevated hsCRP, and local abdominal obesity definition to waist circumference (Females: $\geq 90 \mathrm{~cm}$; Males: $\geq 95 \mathrm{~cm}$ ).

In addition, an ordinal logistic regression model was constructed, with fasting glucose tertiles among subjects with IFG set as the dependent variable. The independent variables included gender, age groups, ethnic groups, abdominal obesity, hypertriglyceridemia, low HDL-C, BMI classification, JNC-8 classification, TAG/HDL-C ratio tertiles, elevated hs-CRP and presence of IR. Regression coefficients $(\beta)$ were calculated with their corresponding confidence intervals $(95 \%$ CI) along with Odds Ratios $\left(e^{\beta}\right)$ and their $95 \%$ CI. Goodness-of-fit parameters were calculated and parallel line testing was performed. Data were analyzed with the Statistical Package for the Social Sciences (SPSS) v.21 for Windows (IBM Inc. Chicago, IL), and de results were considered statistically significant when $p<0.05$.

\section{Results}

\section{Characteristics of the general population}

The sample had 2,230 individuals, $52.6 \%$ were women $(\mathrm{n}=1172)$ with a mean age of $39.3 \pm 15.4$. The prevalence of DM2 was $8.4 \%$ $(n=187)$ and the prevalence of IFG was 19.5\% $(n=435)$ (Figure 1).

\section{Sociodemographic and psycobiological characteristics according to IFG}

Table 1 shows the prevalence of IFG according to sociodemographic and psychobiological habits of the population. Age groups showed the greatest degree of association, displaying a rising prevalence of IFG, from $12.1 \%(n=91)$ in individuals aged $<30$ and years, to $31 \%$ in those 
Citation: Bermúdez V, Salazar J, González R, Ortega A, Calvo M, et al. (2016) Prevalence and Risk Factors associated with Impaired Fasting Glucose in Adults from Maracaibo City, Venezuela. J Diabetes Metab 7: 683. doi:10.4172/2155-6156.1000683

Page 3 of 8

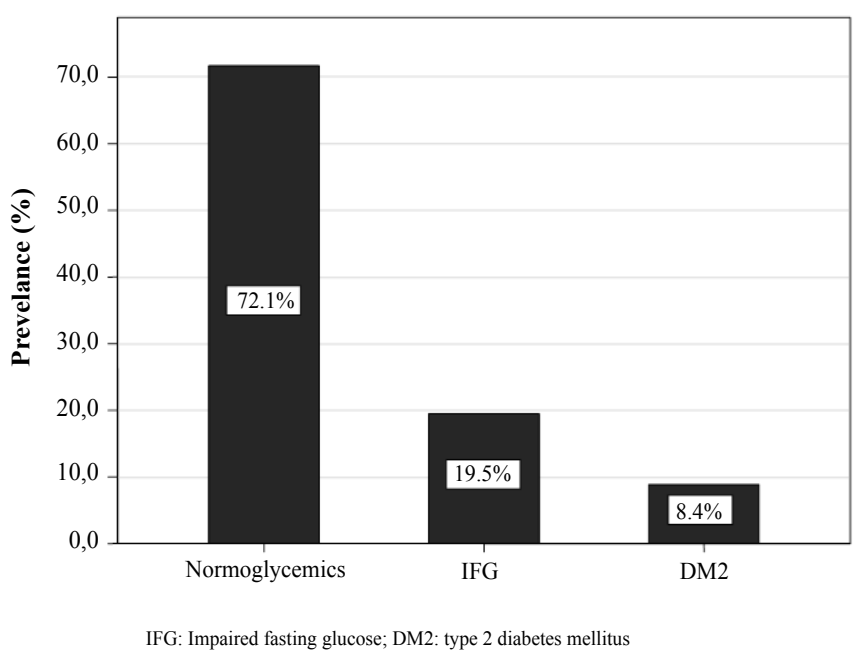

Figure 1: Prevalence of type 2 diabetes mellitus and impaired fasting glucose. Maracaibo City Metabolic Syndrome Prevalence Study, 2016.

aged $\geq 60$ years $\left(n=54, \chi^{2}=63.47 ; p<0.001\right)$. In contrast, regarding leisure-time PA, prevalence of IFG was highest in subjects classified as inactive $(22.1 \% ; n=270)$, and lowest in subjects in Q5 $(11 \% ; n=20)$, $\chi^{2}=15.80 ; \mathrm{p}=0.007$.

\section{Clinical characteristics according to IFG}

Among all clinical features studied (Table 2), IR appeared to be the most closely related to IFG, with these disorders coexisting in $31.4 \%$ of subjects $(\mathrm{n}=252)\left(\chi^{2}=75.44 ; \mathrm{p}<0.0001\right)$. BP classification by the JNC- 8 was also tightly linked to IFG, with a $15.7 \%$ prevalence in normotensive subjects vs $32.9 \%$ in hypertensives; $\chi^{2}=50.01 ; \mathrm{p}<0.0001$.

\section{Risk factors for IFG}

Evaluation of the correlation between risk factors in a multivariate context revealed the presence of IR to be the most important risk factor for IFG in our population $(\mathrm{OR}=2.51 ; 95 \% \mathrm{CI}=1.79-3.52 ; \mathrm{p}<0.01)$, followed by age groups ( $\geq 60$ years: $\mathrm{OR}=2.31 ; 95 \% \mathrm{CI}=1.23-4.35$; $\mathrm{p}<0.01$ ) (Table 3).

\section{Clinical and biochemical characteristics of subjects with IFG}

After assessing the behavior of various clinical and biochemical variables according to fasting glucose tertiles among subjects with IFG, a progressive worsening across tertiles was observed in most variables (Table 4). Although many variables showed a significant association with these fasting glucose tertiles, the presence of elevated hs-CRP was the main risk factor identified in the multivariate analysis $(\mathrm{OR}=2.03$; $95 \% \mathrm{CI}=1.13$ to $3.67 ; \mathrm{p}<0.02)$.

\section{Discussion}

IFG is an intermediate disglycemic stage that precedes T2D [5], which has displayed an alarming rise in prevalence in recent years $[26,27]$. Because of the possible disease-modifying potential of early therapeutic intervention in these subjects, it is of vital importance to evaluate the epidemiological behavior of this metabolic alteration and determine the main risk factors associated with it in our population.

In Latin America, the CARMELA study reported a prevalence of IFG of only $2 \%$, with Mexico and Bogota boasting the highest figures. Meanwhile, the city of Barquisimeto in Venezuela reported only $1 \%$

\begin{tabular}{|c|c|c|c|c|c|c|}
\hline & & \multicolumn{2}{|c|}{ Normoglycemics } & \multicolumn{2}{|c|}{$\begin{array}{l}\text { Impaired } \\
\text { Fasting } \\
\text { Glucose }\end{array}$} & \multirow[t]{2}{*}{$X^{2}(p)$} \\
\hline & & $\mathbf{n}$ & $\%$ & $\mathbf{n}$ & $\%$ & \\
\hline \multirow[t]{2}{*}{ Gender } & Females & 870 & 81.2 & 202 & 18.8 & $8.21(0.004)$ \\
\hline & Males & 736 & 76.0 & 233 & 24.0 & \\
\hline \multirow[t]{3}{*}{$\begin{array}{l}\text { Age groups } \\
\text { (years) }\end{array}$} & $<30$ & 664 & 87.9 & 91 & 12.1 & $63.47(<0.001)$ \\
\hline & $30-59$ & 822 & 73.9 & 290 & 26.1 & \\
\hline & $\geq 60$ & 120 & 69.0 & 54 & 31.0 & \\
\hline \multirow[t]{5}{*}{ Ethnic groups } & Mixed race & 1224 & 78.7 & 332 & 21.3 & $6.09(0.19)$ \\
\hline & Hispanic White & 248 & 77.3 & 73 & 22.7 & \\
\hline & $\begin{array}{c}\text { Afro- } \\
\text { Venezuelan }\end{array}$ & 42 & 72.4 & 16 & 27.6 & \\
\hline & Amerindian & 81 & 86.2 & 13 & 13.8 & \\
\hline & Others & 11 & 91.7 & 1 & 8.3 & \\
\hline \multirow[t]{3}{*}{\begin{tabular}{|c}
$\begin{array}{c}\text { Socioeconomic } \\
\text { status }\end{array}$ \\
\end{tabular}} & Classes I y II & 319 & 75.8 & 102 & 24.2 & $4.71(0.09)$ \\
\hline & Class III & 660 & 80.9 & 156 & 19.1 & \\
\hline & classes IV y V & 627 & 78.0 & 177 & 22.0 & \\
\hline \multirow[t]{2}{*}{$\begin{array}{l}\text { Occupational } \\
\text { Status }\end{array}$} & Un- Employed & 799 & 76.3 & 248 & 23.7 & $3.12(0.08)$ \\
\hline & Employed & 668 & 79.7 & 170 & 20.3 & \\
\hline \multirow[t]{4}{*}{ Family history } & No & 859 & 79.2 & 226 & 20.8 & $3.95(0.27)$ \\
\hline & $\mathrm{T} 2 \mathrm{D}$ & 702 & 78.5 & 192 & 21.5 & \\
\hline & $\begin{array}{c}\text { Type } 1 \\
\text { Diabetes } \\
\text { Mellitus }\end{array}$ & 25 & 80.6 & 6 & 19.4 & \\
\hline & Both of them & 20 & 64.5 & 11 & 35.5 & \\
\hline \multirow[t]{3}{*}{ Smoking Habits } & Non-Smokers & 1143 & 79.6 & 293 & 20.4 & $2.82(0.24)$ \\
\hline & $\begin{array}{l}\text { Current } \\
\text { Smokers }\end{array}$ & 226 & 75.6 & 73 & 24.4 & \\
\hline & Past Smokers & 230 & 77.2 & 68 & 22.8 & \\
\hline \multirow[t]{2}{*}{$\begin{array}{c}\text { Alcohol } \\
\text { Consumption }\end{array}$} & No & 1139 & 80.9 & 269 & 19.1 & $13.19(<0.001)$ \\
\hline & Yes & 467 & 73.8 & 166 & 26.2 & \\
\hline \multirow[t]{6}{*}{$\begin{array}{c}\text { Physical activity } \\
\text { (Work) }\end{array}$} & Inactive & 1187 & 78.3 & 329 & 21.7 & $1.90(0.86)$ \\
\hline & Q1 & 83 & 79.8 & 21 & 20.2 & \\
\hline & Q2 & 82 & 76.6 & 25 & 23.4 & \\
\hline & Q3 & 83 & 79.8 & 21 & 20.2 & \\
\hline & Q4 & 89 & 83.2 & 18 & 16.8 & \\
\hline & Q5 & 82 & 79.6 & 21 & 20.4 & \\
\hline \multirow[t]{6}{*}{$\begin{array}{l}\text { Physical activity } \\
\text { (Transportation) }\end{array}$} & Inactive & 569 & 78.6 & 155 & 21.4 & $3.92(0.56)$ \\
\hline & Q1 & 203 & 81.5 & 46 & 18.5 & \\
\hline & Q2 & 206 & 76.6 & 63 & 23.4 & \\
\hline & Q3 & 210 & 81.4 & 48 & 18.6 & \\
\hline & Q4 & 214 & 78.1 & 60 & 21.9 & \\
\hline & Q5 & 180 & 76.3 & 56 & 23.7 & \\
\hline \multirow[t]{6}{*}{$\begin{array}{c}\text { Physical activity } \\
\text { (Household) }\end{array}$} & Inactive & 402 & 75.0 & 134 & 25.0 & $11.78(0.04)$ \\
\hline & Q1 & 236 & 81.1 & 55 & 18.9 & \\
\hline & Q2 & 252 & 81.8 & 56 & 18.2 & \\
\hline & Q3 & 257 & 82.1 & 56 & 17.9 & \\
\hline & Q4 & 220 & 75.1 & 73 & 24.9 & \\
\hline & Q5 & 239 & 79.7 & 61 & 20.3 & \\
\hline \multirow[t]{6}{*}{$\begin{array}{c}\text { Physical activity } \\
\text { (Leisure) }\end{array}$} & Inactive & 949 & 77.9 & 270 & 22.1 & $15.80(0.007)$ \\
\hline & Q1 & 113 & 72.4 & 43 & 27.6 & \\
\hline & Q2 & 127 & 77.9 & 36 & 22.1 & \\
\hline & Q3 & 130 & 78,8 & 35 & 21,2 & \\
\hline & Q4 & 126 & 80,3 & 31 & 19.7 & \\
\hline & Q5 & 161 & 89.0 & 20 & 11.0 & \\
\hline Total $^{\S}$ & & 1606 & 78.7 & 435 & 21.3 & \\
\hline
\end{tabular}

§Subjects with T2D were excluded from the analysis

Table 1: Sociodemographic and psychobiological characteristics associated with the diagnosis of Impaired Fasting Glucose. Maracaibo City Metabolic Syndrome Prevalence Study, 2016 
Citation: Bermúdez V, Salazar J, González R, Ortega A, Calvo M, et al. (2016) Prevalence and Risk Factors associated with Impaired Fasting Glucose in Adults from Maracaibo City, Venezuela. J Diabetes Metab 7: 683. doi:10.4172/2155-6156.1000683

Page 4 of 8

\begin{tabular}{|c|c|c|c|c|c|}
\hline & \multicolumn{2}{|c|}{ Normoglycemics } & \multicolumn{2}{|c|}{ Impaired Fasting Glucose. } & \multirow{2}{*}{$X^{2}(p)$} \\
\hline & $\mathbf{n}$ & $\%$ & $\mathrm{n}$ & $\%$ & \\
\hline Waist circumference $^{\dagger}$ & & & & & $30.53(<0.0001)$ \\
\hline Normal & 470 & 87.0 & 70 & 13.0 & \\
\hline Elevated & 1136 & 75.7 & 365 & 24.3 & \\
\hline Waist circumference ${ }^{\ddagger}$ & & & & & $48.49(<0.0001)$ \\
\hline Normal & 856 & 85.1 & 150 & 14.9 & \\
\hline Elevated & 750 & 72.5 & 285 & 27.5 & \\
\hline Triacylglycerides (mg/dL) & & & & & $47.25(<0.0001)$ \\
\hline$<150$ & 1256 & 82.3 & 270 & 17.7 & \\
\hline$\geq 150$ & 350 & 68.0 & 165 & 32.0 & \\
\hline HDL-C & & & & & $3.43(0.06)$ \\
\hline Normal & 711 & 80.6 & 171 & 19.4 & \\
\hline Lower & 895 & 77.2 & 264 & 22.8 & \\
\hline BMI & & & & & $28.78(<0.001)$ \\
\hline Normal weight & 566 & 84.2 & 106 & 15.8 & \\
\hline Overweight & 579 & 79.3 & 151 & 20.7 & \\
\hline Obesity & 461 & 72.1 & 178 & 27.9 & \\
\hline JNC-8 Classification & & & & & $50.01(<0.0001)$ \\
\hline Normotension & 708 & 84.3 & 132 & 15.7 & \\
\hline Prehypertension & 613 & 79.0 & 163 & 21.0 & \\
\hline Hypertension & 285 & 67.1 & 140 & 32.9 & \\
\hline hs-CRP (mg/L) & & & & & $4.86(0.03)$ \\
\hline$<0.765$ & 817 & 83.0 & 167 & 17.0 & \\
\hline$\geq 0.765$ & 237 & 77.5 & 69 & 22.5 & \\
\hline Insulin Resistance ${ }^{\pi}$ & & & & & $75.44(<0.0001)$ \\
\hline Absent & 892 & 85.4 & 152 & 14.6 & \\
\hline Present & 550 & 68.6 & 252 & 31.4 & \\
\hline Total§ & 1606 & 78.7 & 435 & 21.3 & \\
\hline \multicolumn{6}{|c|}{$\begin{array}{l}\text { BMI=Body Mass Index; hs- CRP= High-sensitivity C-reactive protein; JNC-8=Eighth Joint National Committee } \\
{ }^{\dagger} \text { Criteria by IDF Men: } \geq 90 \mathrm{~cm} \text {; Women: } \geq 80 \mathrm{~cm} \text {. } \\
\text { ₹Criteria according local criteria (Men: } \geq 95 \mathrm{~cm} \text {; Women: } \geq 90 \mathrm{~cm} \text { ). } \\
\text { THOMA2-IR } \geq 2 \\
\text { \$They are excluded from the analysis of subjects with diabetes mellitus }\end{array}$} \\
\hline
\end{tabular}

Table 2: Clinical features associated with Impaired Fasting Glucose. Maracaibo City Metabolic Syndrome Prevalence Study, 2016.

\begin{tabular}{|c|c|c|c|c|c|c|}
\hline & \multicolumn{4}{|c|}{ Model $1^{*}$} & \multicolumn{2}{|l|}{ Modelo $2^{* *}$} \\
\hline & Crude Odds Ratio (Cl 95\% ${ }^{a}$ ) & $p^{b}$ & Adjusted Odds Ratio (Cl 95\% $\left.{ }^{a}\right)$ & $p^{b}$ & Adjusted Odds Ratio $\left(\mathrm{Cl} 95 \%{ }^{a}\right)$ & $p^{b}$ \\
\hline \multicolumn{7}{|c|}{ Age groups (years) } \\
\hline$<30$ & 1.00 & - & 1.00 & - & 1.00 & - \\
\hline $30-49$ & $2.57(1.99-3.33)$ & $<0.01$ & $1.99(1.46-2.71)$ & $<0.01$ & $2.09(1.39-3.14)$ & $<0.01$ \\
\hline$\geq 60$ & $3.28(2.23-4.84)$ & $<0.01$ & $2.47(1.54-3.96)$ & $<0.01$ & $2.31(1.23-4.35)$ & $<0.01$ \\
\hline \multicolumn{7}{|c|}{ Alcohol consumption ${ }^{c}$} \\
\hline No & 1.00 & - & 1.00 & - & 1.00 & - \\
\hline Yes & $1.51(1.21-1.88)$ & $<0.01$ & $1.28(0.98-1.67)$ & 0.07 & $1.49(1.04-2.12)$ & 0.03 \\
\hline \multicolumn{7}{|c|}{ Hypertriglyceridemia $^{f}$} \\
\hline Absent & 1.00 & - & 1.00 & - & 1.00 & - \\
\hline Present & $2.19(1.75-2.75)$ & $<0.01$ & $1.42(1.09-1.86)$ & 0.01 & $1.35(0.95-1.94)$ & 0.09 \\
\hline \multicolumn{7}{|c|}{ JNC-8 Classification } \\
\hline Normotense & 1.00 & - & 1.00 & - & 1.00 & - \\
\hline Pre-hypertensive & $1.43(1.11-1.84)$ & $<0.01$ & $1.05(0.78-1.40)$ & 0.77 & $0.93(0.54-1.35)$ & 0.68 \\
\hline Hypertensive & $2.64(2.00-3.47)$ & $<0.01$ & $1.61(1.15-2.25)$ & $<0.01$ & $1.19(0.77-1.85)$ & 0.44 \\
\hline \multicolumn{7}{|c|}{ Elevated Waist circumference } \\
\hline Absent & - & - & 1.00 & - & 1.00 & - \\
\hline Present & - & - & $1.13(0.79-1.59)$ & 0.51 & $1.62(1.07-2.45)$ & 0.02 \\
\hline \multicolumn{7}{|c|}{ Insulin-resistance ${ }^{g}$} \\
\hline Absent & 1.00 & - & 1.00 & - & 1.00 & - \\
\hline Present & $2.69(2.14-3.38)$ & $<0.01$ & $2.33(1.81-2.99)$ & $<0.01$ & $2.51(1.79-3.52)$ & $<0.01$ \\
\hline
\end{tabular}

a Confidence interval (95\%); b Significance level; c Alcohol consumption > 1 gr/daily; d Triglycerides $\geq 150 \mathrm{mg} / \mathrm{dL}$; e HOMA2-IR $\geq 2$

*Model 1: Adjustment for gender, age groups, ethnic groups, family history of diabetes mellitus, employment status, smoking habits, alcohol consumption, home-sphere physical activity, leisure-time physical activity, hypertriglyceridemia, low HDL -C, JNC-8 classification, BMI categories, presence of insulin resistance and elevated waist circumference: Men: $\geq 90 \mathrm{~cm}$; Women: $\geq 80 \mathrm{~cm}$.

${ }^{* *}$ Model 2: Similar adjustment to model 1 but elevated waist circumference is adjusted (Men: $\geq 95 \mathrm{~cm}$; Women: $\geq 90 \mathrm{~cm}$ ) and elevated hs-CRP ( $\geq 0,765 \mathrm{mg} / \mathrm{L}$ ) is added. Table 3: Logistic regression models of risk factors for Impaired Fasting Glucose. Maracaibo City Metabolic Syndrome Prevalence Study, 2016. 


\begin{tabular}{|c|c|c|c|c|c|c|c|c|c|c|}
\hline & \multicolumn{2}{|c|}{$\begin{array}{c}\text { Tertile } 1 \\
(100-102.9 \mathrm{mg} / \mathrm{dL}) \\
{[\mathrm{A}]}\end{array}$} & \multicolumn{2}{|c|}{$\begin{array}{c}\text { Tertile } 2 \\
(103-107.9 \mathrm{mg} / \mathrm{dL}) \\
\text { [B] }\end{array}$} & \multicolumn{2}{|c|}{$\begin{array}{c}\text { Tertile 3 } \\
\text { ( } \geq 108 \mathrm{mg} / \mathrm{dL}) \\
{[\mathrm{C}]}\end{array}$} & \multirow[t]{2}{*}{$p^{*}$} & \multirow[t]{2}{*}{$A$ vs $B$} & \multirow[t]{2}{*}{ A vs $C$} & \multirow[t]{2}{*}{ B vs C } \\
\hline & Media & $\mathrm{DE}$ & Media & $\mathrm{DE}$ & Media & DE & & & & \\
\hline Age (years) & 40.6 & 15.1 & 44.2 & 14.9 & 46.2 & 14.2 & 0.003 & 0.08 & 0.002 & 0.41 \\
\hline BMI $\left(\mathrm{Kg} / \mathrm{m}^{2}\right)$ & 28.5 & 6.5 & 29.1 & 5.6 & 31.5 & 7.9 & $<0.001$ & 0.75 & 0.001 & 0.006 \\
\hline Waist Circumference (cm) & 95.6 & 15.1 & 97.7 & 13.3 & 104.0 & 18.8 & $<0.001$ & 0.40 & $<0.001$ & 0.004 \\
\hline Basal glycemia (mg/dL) & 100.9 & 0.8 & 104.8 & 1.5 & 113.8 & 4.8 & $<0.001$ & $<0.001$ & $<0.001$ & $<0.001$ \\
\hline Insulin (UI/L) & 15.8 & 8.6 & 18.2 & 14.3 & 18.7 & 10.9 & 0.100 & 0.60 & 0.09 & 0.43 \\
\hline HOMA2- $\beta$ cell & 133.2 & 48.2 & 134.9 & 65.5 & 120.2 & 46.9 & 0.03 & 0.91 & 0.05 & 0.09 \\
\hline HOMA2-S & 53.1 & 26.9 & 53.1 & 47.9 & 45.3 & 25.1 & 0.03 & 0.51 & 0.02 & 0.22 \\
\hline HOMA2-IR & 2.36 & 1.21 & 2.70 & 1.89 & 2.88 & 1.59 & 0.03 & 0.49 & 0.02 & 0.24 \\
\hline Total cholesterol (mg/dL) & 193.4 & 42.0 & 203.9 & 60.1 & 208.1 & 47.7 & 0.03 & 0.24 & 0.02 & 0.52 \\
\hline Triacilglycerides (mg/dL) & 132.8 & 96.7 & 143.8 & 112.8 & 167.2 & 109.5 & $<0.001$ & 0.57 & $<0.001$ & 0.008 \\
\hline HDL-C (mg/dL) & 45.1 & 11.5 & 43.1 & 13.2 & 41.3 & 10.5 & 0.02 & 0.19 & 0.02 & 0.53 \\
\hline VLDL-C (mg/dL) & 26.6 & 19.4 & 28.8 & 22.6 & 33.6 & 21.9 & 0.02 & 0.66 & 0.02 & 0.13 \\
\hline LDL-C (mg/dL) & 122.8 & 36.2 & 130.9 & 44.2 & 134.5 & 39.9 & 0.09 & 0.51 & 0.07 & 0.51 \\
\hline Cholesterol Non HDL & 148.2 & 41.5 & 160.8 & 60.2 & 166.8 & 48.0 & 0.009 & 0.11 & 0.007 & 0.56 \\
\hline Index TAG/HDL ${ }^{\dagger}$ & 2.4 & $1.5-4.3$ & 2.9 & $1.9-4.4$ & 3.5 & $2.3-5.5$ & $<0.001$ & - & - & - \\
\hline Lipoprotein(a) (mg/dL) & 28.6 & 12.9 & 26.9 & 15.9 & 25.4 & 14.5 & 0.209 & 0.62 & 0.18 & 0.65 \\
\hline Systolic blood pressure $(\mathrm{mmHg})$ & 120.9 & 17.9 & 122.8 & 17.6 & 125.7 & 16.7 & 0.04 & 0.59 & 0.03 & 0.24 \\
\hline Diastolic blood pressure $(\mathrm{mmHg})$ & 78.8 & 12.5 & 79.7 & 11.9 & 80.6 & 11.8 & 0.40 & 0.75 & 0.37 & 0.79 \\
\hline hs-CRP $(\mathrm{mg} / \mathrm{L})^{\dagger}$ & 0.397 & $0.208-0.758$ & 0.383 & $0.139-0.674$ & 0.607 & $\begin{array}{l}0.231- \\
1.027\end{array}$ & 0.05 & - & - & - \\
\hline
\end{tabular}

Table 4: Clinical and biochemical characteristics in subjects with Impaired Fasting Glucose according to fasting glucose tertiles. Maracaibo City Metabolic Syndrome Prevalence Study, 2016

[28] of IFG prevalence. All of these are lower than estimations in the USA (26\%) [4]. In contrast to the CARMELA study, the PERUDIAB study recently evaluated 1,677 Peruvian individuals aged $\geq 25$ years, estimating a general IFG prevalence of $22.4 \%$ [29]. Reports on prediabetes are scarce in Venezuela, although there is a report from a rural population in Merida State, in the Andean Region, which found 18.6\% of the individuals to have IFG [30], a similar rate to the findings in our study (19.5\%).

Evaluation of IFG by gender showed a higher prevalence in males as has been described in other populations [31,32], similarly echoing previous reports $[27,28,33]$, prevalence increasing with age in both univariate and multivariate analysis (Table 5). This might be associated with senescent changes, such as increased visceral adiposity [34] decreased lean mass [35] and reduced PA [36] all having a direct influence on IR development. The decrease in PA may play a particularly important role in this process, as PA improves glucose metabolism by favoring its uptake by target organs, depleting muscular glycogen, and inducing favorable changes in lipid metabolism $[37,38]$.

Furthermore, alcohol consumption was associated with a higher risk of having this metabolic alteration, similar to findings reported by Cullmann et al. [39] in 111 pre-diabetic Swedish individuals, where alcohol consumption was recognized as a risk factor in men, mainly in beer drinkers (OR: 1.84, 95\% CI: 1.13-3.01, p<0,05). This effect appears to be dependent on the amount and type of alcohol consumed, as for women, for example, the moderate consumption of wine was found to be protective, while the excessive consumption of spirituous beverages was identified as a risk factor (OR: 2.41, 95\% CI 1.47-3.96). Additionally, our research group has demonstrated that the effect of alcohol consumption on the components of the metabolic syndrome appears to be dose-dependent in our population, with an approximate intake of 4-6 beers, 3-5 spirituous beverages or 4-7 cups of wine found to be a risk factor for hyperglycemia among males (OR: $1.99,95 \% \mathrm{CI}$ : $1.20-3.33 ; \mathrm{p}<0.01)[40]$.

Regarding clinical characteristics, in the multivariate context the results showed that only subjects with abdominal obesity had a higher risk of IFG similar to results by Diaz et al. [8] in the PREDAPS study, where 1184 Spanish pre-diabetic individuals were evaluated. In this study, abdominal obesity was considered a risk factor in both genres, indeed obesity is closely related to metabolic disorders of carbohydrates, especially visceral adiposity. In the context of adiposopathy -characterized by increased signaling of proinflammatory cytokines such as TNF- $\alpha$, MCP- 1, IL- $1 \beta$ and macrophage infiltration in adipose tissue-[41] TNF- $\alpha$ interrupts the insulin signaling cascade by phosphorylating serine-threonine sidechains in the insulin receptor substrate (IRS) altering its enzymatic activity and preventing GLUT4 translocation in insulin-dependent tissues, being a molecular mechanism of utmost importance in IFG appearance [42] In addition, TNF- $\alpha$ increases lipolysis and decreases biosynthesis of triacylglycerols via peroxisome proliferator-activated receptor gamma (PPAR $\gamma$ ) signaling in adipose tissue, consequently causing an increase in free fatty acids (FFA) release into splanchnic circulation (43). According to Shulman et al. [43] this phenomenon favors FFA storage in ectopic tissues such as the liver and muscle, increasing the intracellular concentration of intermediates of fatty acid metabolism such as acyl-CoA, ceramides and diacylglycerol which are also involved in the phosphorylation of IRS and therefore in inhibiting effects [44], suggesting a close relationship between obesity, the presence of IR and the appearance of IFG.

Hypertension was also found to be a risk factor for IFG in our population, in resemblance to the PREDAPS study, where hypertensive subjects had a risk 2.33 times higher risk of IFG [8]. Nevertheless, this 
Citation: Bermúdez V, Salazar J, González R, Ortega A, Calvo M, et al. (2016) Prevalence and Risk Factors associated with Impaired Fasting Glucose in Adults from Maracaibo City, Venezuela. J Diabetes Metab 7: 683. doi:10.4172/2155-6156.1000683

Page 6 of 8

\begin{tabular}{|c|c|c|c|c|c|c|c|c|c|}
\hline & \multicolumn{2}{|c|}{$\begin{array}{c}\text { Tertile } 1 \\
(\mathbf{1 0 0 - 1 0 2 . 9} \mathrm{mg} / \mathrm{dL})\end{array}$} & \multicolumn{2}{|c|}{$\begin{array}{c}\text { Tertile } 2 \\
(103-107.9 \mathrm{mg} / \\
\mathrm{dL})\end{array}$} & \multicolumn{2}{|c|}{$\begin{array}{c}\text { Tertile } 3 \\
(\geq 108 \mathrm{mg} / \mathrm{dL})\end{array}$} & \multirow[t]{2}{*}{$x^{2}(p)$} & \multirow[t]{2}{*}{$\beta^{*}(\mathrm{Cl} 95 \%) ; p$} & \multirow[t]{2}{*}{ OR (Cl95\%) } \\
\hline & $\mathbf{n}$ & $\%$ & $\mathbf{n}$ & $\%$ & $\mathbf{n}$ & $\%$ & & & \\
\hline Waist circumference $\ddagger$ & & & & & & & $11.26(0.004)$ & & \\
\hline Normal & 55 & 36.7 & 53 & 35.3 & 42 & 28.0 & & 0 & \\
\hline Elevated & 68 & 23.9 & 96 & 33.7 & 121 & 42.5 & & $0.12(-0.88-0.65) ; 0.76$ & $1.13(0.41-1.91)$ \\
\hline Triacilglycerides (mg/dL) & & & & & & & $9.04(0.01)$ & & \\
\hline$<150$ & 86 & 31.9 & 97 & 35.9 & 87 & 32.2 & & 0 & 0 \\
\hline$\geq 150$ & 37 & 22.4 & 52 & 31.5 & 76 & 46.1 & & $0.18(-1.09-0.73) ; 0.69$ & $1.19(0.33-2.07)$ \\
\hline HDL-C & & & & & & & $4.42(0.11)$ & & \\
\hline Normal & 58 & 33.9 & 54 & 31.6 & 59 & 34.5 & & 0 & 0 \\
\hline Low & 65 & 24.6 & 95 & 36.0 & 104 & 39.4 & & $-0.13(-0.48-0.74) ; 0.67$ & $0.87(0.61-2.09)$ \\
\hline BMI Classification & & & & & & & $11.56(0.02)$ & & \\
\hline Normal weight & 37 & 34.9 & 39 & 36.8 & 30 & 28.3 & & 0 & 0 \\
\hline Overweight & 47 & 31.1 & 53 & 35.1 & 51 & 33.8 & & $-0.15(-0.95-0.62) ; 0.63$ & $0.86(0.39-1.86)$ \\
\hline Obesity & 39 & 21.9 & 57 & 32.0 & 82 & 46.1 & & $0.63(-0.82-0.95) ; 0.86$ & $1.88(0.44-2.59)$ \\
\hline JNC-8 Classification & & & & & & & $6.46(0.17)$ & & \\
\hline Normotense & 43 & 32.6 & 47 & 35.6 & 42 & 31.8 & & 0 & 0 \\
\hline Pre-hypertensive & 49 & 30.1 & 56 & 34.4 & 58 & 35.6 & & $0.03(-0.57-0.61) ; 0.96$ & $1.03(0.56-1.84)$ \\
\hline Hypertensive & 31 & 22.1 & 46 & 32.9 & 63 & 45.0 & & $0.50(-0.22-1.17) ; 0.17$ & $1.64(0.80-3.22)$ \\
\hline hs-CRP (mg/L) & & & & & & & $12.02(0.002)$ & & \\
\hline$<0.765$ & 54 & 32.3 & 65 & 38.9 & 48 & 28.7 & & 0 & 0 \\
\hline$\geq 0.765$ & 17 & 24.6 & 16 & 23.2 & 36 & 52.2 & & $0.71(0.12-1.30) ; 0.02$ & $2.03(1.13-3.67)$ \\
\hline Insulinresistence $\pi$ & & & & & & & $2.09(0.35)$ & & \\
\hline Absent & 44 & 28.9 & 58 & 38.2 & 50 & 32.9 & & 0 & 0 \\
\hline Present & 66 & 26.2 & 85 & 33.7 & 101 & 40.1 & & $0.39(-0.19-0.96) ; 0.17$ & $1.48(0.82-2.61)$ \\
\hline TAG/HDL ratio & & & & & & & $16.59(<0.01)$ & & \\
\hline$<1.74$ & 39 & 31.7 & 34 & 22.8 & 22 & 13.5 & & 0 & \\
\hline $1.74-3.36$ & 39 & 31.7 & 55 & 36.9 & 54 & 33.1 & & $0.28(-1.23-1.12) ; 0.93$ & $1.32(0.29-3.07)$ \\
\hline$>3.36$ & 45 & 36.6 & 60 & 40.3 & 87 & 53.4 & & $-0.05(-0.49-1.04) ; 0.48$ & $0.95(0.61-2.83)$ \\
\hline Total§ & 123 & 28.3 & 149 & 34.3 & 163 & 37.4 & & & \\
\hline \multicolumn{10}{|c|}{$\begin{array}{l}\text { BMI = body mass index; JNC-8 }=8 \text { th National Joint Committee for Hypertension } \\
\text { } \text { CCriteria according to EPSMM (Men: } \geq 95 \mathrm{~cm} \text {; Women: } \geq 90 \mathrm{~cm}) \text {. } \\
\text { THOMA2-IR } \geq 2 \\
\text { \$Subjects with diabetes mellitus were excluded from the analysis } \\
\text { *Ordinal regression model adjusted for gender, age groups, ethnic groups, leis } \\
\text { classification, JNC- } 8 \text { classification, elevated hs-CRP and presence of insulin resis } \\
\text { Model adjustment information: }\left(X^{2}=34.69 ; p=0.007\right) \\
\text { Pseudo R-Squared: Cox and Snell }(0.14) \text { - Nagelkerke }(0.16)-\text { McFadden }(0.07) \\
\text { Parallel line test }\left(X^{2}=14.17 ; p=0.66\right)\end{array}$} \\
\hline
\end{tabular}

Table 5: Clinical characteristics in patients with Impaired Fasting Glucose according to fasting glucose tertiles. Maracaibo City Metabolic Syndrome Prevalence Study, 2016

association was no longer significant after adjusting the model by abdominal circumference and elevated hs-CRP, which might imply that this co-relation between hypertension and alteration of IFG depends on other factors different from IR, such as a certain level of chronic inflammation and oxidative stress, as has been proposed in previous publications [45].

Finally, when evaluating individuals with IFG exclusively, we observed that clinical and metabolic parameters are altered by increasing levels of glycemia. Moreover, when multivariate analysis revealed the presence of elevated hs-CRP to be the factor to most closely related to the highest tertile of fasting glycemia, similar to the findings of Jaiswal et al. [46]. Indeed, prospective studies have described elevated hs-CRP as an independent risk factor for the development of both T2D [47] and pre-diabetes [48], being considered as a chronic inflammation marker closely related to IR, and playing a central role in the development and progression of IFG, metabolic syndrome and T2D [49]. It is also important to note that elevated hsCRP was a significant risk factor only when analyzing subjects with
IFG. Molecular mechanisms that could explain this unique correlation in this group of subjects may be an upregulation of CRP expression by IR state, counteracting the physiological effects of insulin in early phase synthesis of hepatic proteins [50], existing major acute phase protein synthesis, which might explain why hs-CRP is a better predicting factor only in patients with established metabolic disorders.

Limitations of this study include its cross-sectional design, which does not allow establishment of causality, and the lack of assessment of nutritional habits, which repr sent an important factor contributing to dysglycemia. Likewise, even though there are many markers for low grade inflammation, hs-CRP was the only one who rendered significant results in the multivariant analysis. However, more research is required in order to properly depict the mechanistics of this association in our population. Finally, the design of the study did not originally include the evaluation of $2 \mathrm{hr}$ oral glucose tolerance test or postpandrial measurements. Nevertheless, in the upcoming second phase of the project, we are considering this variable as a new inclusion in our research. 
Citation: Bermúdez V, Salazar J, González R, Ortega A, Calvo M, et al. (2016) Prevalence and Risk Factors associated with Impaired Fasting Glucose in Adults from Maracaibo City, Venezuela. J Diabetes Metab 7: 683. doi:10.4172/2155-6156.1000683

In conclusion, our results highlight the responsibility of clinicians for the early detection of subjects with IFG, especially in populations with high prevalence of risk factors such as obesity, physical inactivity and metabolic syndrome [51-53]. IFG prevalence in our population is similar to worldwide reports, in contrast to the low prevalence previously reported in Latin America in past decades. IFG is also linked to various cardiovascular risk factors in our population such as age, alcohol consumption, abdominal obesity; suggesting these patients as candidates for early therapeutic intervention as recommended by the ADA [54]. Lastly, hs-CRP may be a useful predicting factor for T2D among subjects with IFG.

\section{Funding}

This work was supported by research grant $N^{\circ}$ CC-0437-10-21-09-10 from the Technological, Humanistic, and Scientific Development Council (Consejo de Desarrollo Científico, Humanístico y Tecnológico; CONDES), University of Zulia, and research grant $\mathrm{N}^{\circ}$. FZ-0058-2007 from Fundacite-Zulia.

\section{Disclosure}

The authors have are no conflicts of interest to disclose.

\section{References}

1. International Diabetes Federation (2013) International Diabetes Atlas [online version] 6th edn Brussels, Belgium: International Diabetes Federation 12: 6-9.

2. Genuth S, Alberti KG, Bennett P, Buse J, Defronzo R, et al. (2003) Follow-up report on the diagnosis of diabetes mellitus. Diabetes Care 26: 3160-3167.

3. American Diabetes Association (2014) Diagnosis and Classification of Diabetes Mellitus. Diabetes Care 37: S81-S90.

4. CDC (2011) National diabetes fact sheet: national estimates and general information on diabetes and prediabetes in the United States. Atlanta, GA: US Department of Health and Human Services 22: 13-27.

5. Cowie CC, Rust KF, Ford ES, Eberhardt MS, Byrd-Holt DD, et al. (2009) Full accounting of diabetes and pre-diabetes in the U.S. population in 1988-1994 and 2005-2006. Diabetes Care 32: 287-294.

6. Yeboah J, Bertoni AG, Herrington DM, Post WS, Burke GL (2011) Impaired fasting glucose and the risk of incident diabetes mellitus and cardiovascular events in an adult population: MESA (Multi-Ethnic Study of Atherosclerosis). J Am Coll Cardiol 58: 140-146.

7. Abdul-Ghani MA, Tripathy D, DeFronzo RA (2006) Contributions of beta-cell dysfunction and insulin resistance to the pathogenesis of impaired glucose tolerance and impaired fasting glucose. Diabetes Care 29: 1130-1139.

8. Díaz-Redondo A, Giráldez-García C, Carrillo L, Serrano R, García-Soidán FJ, et al. (2015) Modifiable risk factors associated with prediabetes in men and women: a cross-sectional analysis of the cohort study in primary health care on the evolution of patients with prediabetes (PREDAPS-Study). BMC Fam Pract 16: 5.

9. Nathan DM, Davidson MB, DeFronzo RA, Heine RJ, Henry RR, et al. (2007) Impaired fasting glucose and impaired glucose tolerance: implications for care. Diabetes Care 30: 753-759.

10. Tuso $P$ (2014) Prediabetes and lifestyle modification: time to prevent a preventable disease. Perm J 18: 88-93.

11. DREAM (Diabetes REduction Assessment with ramipril and rosiglitazone Medication) Trial Investigators, Gerstein HC, Yusuf S, Bosch J, Pogue J, et al. (2006) Effect of rosiglitazone on the frequency of diabetes in patients with impaired glucose tolerance or impaired fasting glucose: a randomised controlled trial. Lancet 368: 1096-1105.

12. Bermúdez V, Marcano RP, Cano C, Arráiz N, Amell A, et al. (2010) The Maracaibo city metabolic syndrome prevalence study: design and scope. Am J Ther 17: 288-294.

13. Méndez-Castellano H, De Méndez MC (1986) Estratificación social y biología humana: método de Graffar modificado. Arch Ven Pueric Pediatr 49: 93-104.

14. Zhang XF, Attia J, D'Este C, Yu XH (2004) Prevalence and magnitude of classical risk factors for stroke in a cohort of 5092 Chinese steelworkers over 13.5 years of follow-up. Stroke 35: 1052-1056

15. Bermúdez V, Torres $\mathrm{Y}$, Apruzzese V, Martínez MS, Chávez M, et al.
(2014) Alcohol drinking patterns in the adult population from the Maracaibo municipality, Zulia - Venezuela. Revista Latinoamericana de Hipertensión 9: 21-28.

16. (2015) International Physical Activity Questionnaire.

17. James PA, Oparil S, Carter BL, Cushman WC, Dennison-Himmelfarb C, et al (2014) evidence-based guideline for the management of high blood pressure in adults: report from the panel members appointed to the Eighth Joint National Committee (JNC 8). JAMA 311: 507-520.

18. World Health Organization (2003) The World Health Report 2: 32-41.

19. Holt JB, Huston SL, Heidari K, Schwartz R, Gollmar CW, et al. (2015) Indicators for chronic disease surveillance - United States, 2013. MMWR Recomm Rep 64: 1-246.

20. Friedewald WT, Levy RI, Fredrickson DS (1972) Estimation of the concentration of low-density lipoprotein cholesterol in plasma, without use of the preparative ultracentrifuge. Clin Chem 18: 499-502.

21. Chamberlain JJ, Rhinehart AS, Shaefer CF, Neuman A (2016) Diagnosis and Management of Diabetes: Synopsis of the 2016 American Diabetes Association Standards of Medical Care in Diabetes. Ann Intern Med 164: 542-52.

22. Alberti K, Eckel R, Grundy S, Zimmer PZ, Cleeman JI, et al. (2009) Harmonizing the Metabolic Syndrome: A Joint Interim Statement of the International Diabetes Federation Task Force on Epidemiology and Prevention: National Heart, Lung, and Blood Institute; American Heart Association; World Heart Federation; International Atherosclerosis Society; International Association for the Study of Obesity. Circulation 120: 1640-1645.

23. Bermúdez V, Rojas J, Salazar J, Anez R, Chávez-Castillo M, et al. (2014) Optimal Waist Circumference Cut-Off Point for Multiple Risk Factor Aggregation: Results from the Maracaibo City Metabolic Syndrome Prevalence Study. Epidemiology Research International 718571

24. Bermúdez V, Rojas J, Martínez MS, Apruzzese V, Chávez-Castillo M, et al. (2014) Epidemiologic Behavior and Estimation of an Optimal Cut-Off Point for Homeostasis Model Assessment-2 Insulin Resistance: A Report from a Venezuelan Population. International Scholarly Research Notices 6: 162-171.

25. Bermúdez V, Cabrera M, Mendoza L, Chávez M, Martínez MS, et al. (2013) Epidemiological behavior of high -sensitivity C-Reactive Protein (hs-CRP) in adult individuals in the Maracaibo city, Venezuela. Revista Latinoamericana de Hipertensión 8: 16-24.

26. Bullard KM, Saydah SH, Imperatore G, Cowie CC, Gregg EW, et al. (2013) Secular changes in U.S. Prediabetes prevalence defined by hemoglobin A1c and fasting plasma glucose: National Health and Nutrition Examination Surveys, 1999-2010. Diabetes Care 36: 2286-2293.

27. Sahai S, Vyas D, Sharma S (2011) Impaired Fasting Glucose: A Study of its Prevalence Documented at a Tertiary Care Centre of Central India and its Association with Anthropometric Variables. JIACM 12: 187-192.

28. Escobedo J, Buitrón LV, Velasco MF, Ramírez JC, Hernández R, et al. (2009) High prevalence of diabetes and impaired fasting glucose in urban Latin America: the CARMELA Study. Diabet Med 26: 864-871.

29. Seclen S, Rosas M, Arias A, Huayta E, Medina C (2015) Prevalence of diabetes and impaired fasting glucose in Peru: report from PERUDIAB, a national urban population-based longitudinal study. BMJ Open Diab Res Care 3: e000110.

30. González-Rivas JP, Nieto-Martínez R, Molina T, García RJ, Ugel E, et al (2011) Prevalencia de síndrome metabólico, obesidad y alteración de la glucemia en ayunas en adultos del páramo del Estado Mérida, Venezuela (estudio VEMSOLS). Med Interาna (Caracas) 27: 262-267.

31. Hilawe EH, Yatsuya H, Kawaguchi L, Aoyama A (2013) Differences by sex in the prevalence of diabetes mellitus, impaired fasting glycaemia and impaired glucosetolerance in sub-Saharan Africa: a systematic review and metaanalysis. Bull World Health Organ 91: 671D-682D.

32. Williams JW, Zimmet PZ, Shaw JE, de Courten MP, Cameron AJ, et al. (2003) Gender differences in the prevalence of impaired fasting glycaemia and impaired glucose tolerance in Mauritius. Does sex matter? Diabet Med 20 915-920.

33. Henry $P$, Thomas $F$, Benetos A, Guize $L$ (2002) Impaired fasting glucose, blood pressure and cardiovascular disease mortality. Hypertension 40: 458-463.

34. Michalakis K, Goulis DG, Vazaiou A, Mintziori G, Polymeris A, et al. (2013) Obesity in the ageing man. Metabolism 62: 1341-1349. 
Citation: Bermúdez V, Salazar J, González R, Ortega A, Calvo M, et al. (2016) Prevalence and Risk Factors associated with Impaired Fasting Glucose in Adults from Maracaibo City, Venezuela. J Diabetes Metab 7: 683. doi:10.4172/2155-6156.1000683

Page 8 of 8

35. Atkins JL, Whincup PH, Morris RW, Wannamethee SG (2014) Low muscle mass in older men: the role of lifestyle, diet and cardiovascular risk factors. J Nutr Health Aging 18: 26-33.

36. León-Latre M, Moreno-Franco B, Andrés-Esteban EM, Ledesma M, Laclaustra $M$, et al. (2014) Sedentary lifestyle and its relation to cardiovascular risk factors, insulin resistance and inflammatory profile. Rev Esp Cardiol (Engl Ed) 67: 449-455.

37. Borghouts LB, Keizer HA (2000) Exercise and insulin sensitivity: a review. Int J Sports Med 21: 1-12.

38. Gregg EW, Gerzoff RB, Caspersen CJ, Williamson DF, Narayan KM (2003) Relationship of walking to mortality among US adults with diabetes. Arch Intern Med 163: 1440-1447

39. Cullmann M, Hilding A, Östenson CG (2012) Alcohol consumption and risk of pre-diabetes and type 2 diabetes development in a Swedish population. Diabet Med 29: 441-452.

40. Bermúdez V, Martínez MS, Chávez-Castillo M, Olivar LC, Morillo J, et al. (2015) Relationship between Alcohol Consumption and Components of the Metabolic Syndrome in Adult Population from Maracaibo City, Venezuela. Advances in Preventive Medicine 35: 25-47.

41. Xu H, Barnes GT, Yang Q, Tan G, Yang D, et al. (2003) Chronic inflammation in fat plays a crucial role in the development of obesity-related insulin resistance. J Clin Invest 112: 1821-1830.

42. Bouzakri K, Zierath JR (2007) MAP4K4 gene silencing in human skeleta muscle prevents tumor necrosis factor-alpha-induced insulin resistance. J Biol Chem 282: 7783-7789.

43. Guilherme A, Virbasius JV, Puri V, Czech MP (2008) Adipocyte dysfunctions linking obesity to insulin resistance and type 2 diabetes. Nat Rev Mol Cell Biol 9: 367-377.

44. Shulman GI (2000) Cellular mechanisms of insulin resistance. J Clin Invest 106: 171-176.
45. Ruiz-Nunez B, Pruimboom L, Dijck-Brouwer DA, Muskiet FA (2013) Lifestyle and nutritional imbalances associated with Western diseases: causes and consequences of chronic systemic low-grade inflammation in an evolutionary context. J Nutr Biochem 24: 1183-1201.

46. Jaiswal A, Tabassum R, Podder A, Ghosh S, Tandon N, et al. (2012) Elevated level of C-reactive protein is associated with risk of prediabetes in Indians. Atherosclerosis 222: 495-501.

47. Pradhan AD, Manson JE, Rifai N, Buring JE, Ridker PM (2001) C-reactive protein, interleukin 6 , and risk of developing type 2 diabetes mellitus. JAMA 286: 327-334.

48. Doi Y, Kiyohara Y, Kubo M, Tanizaki Y, Okubo K, et al. (2005) Relationship between C-reactive protein and glucose levels in community-dwelling subjects without diabetes: the Hisayama Study. Diabetes Care 28: 1211-1213.

49. Pickup JC, Crook MA (1998) Is type II diabetes mellitus a disease of the innate immune system? Diabetologia 41: 1241-1248.

50. Campos SP, Baumann H (1992) Insulin is a prominent modulator of the cytokine-stimulated expression of acute-phase plasma protein genes. Moll Cell Biol 12: 1789-1797.

51. Bermúdez V, Pacheco M, Rojas J, Córdova E, Velázquez R, et al. (2012) Epidemiologic behavior of obesity in the Maracaibo City metabolic syndrome prevalence study. PLoS One 7: e35392.

52. Bermúdez VJ, Rojas JJ, Córdova EB, Añez R, Toledo A, et al. (2013) International physical activity questionnaire overestimation is ameliorated by individual analysis of the scores. Am J Ther 20: 448-458.

53. Bermúdez V, Rojas J, Salazar J, Calvo MJ, Morillo J, et al. (2014) The Maracaibo city metabolic syndrome prevalence study: primary results and agreement level of 3 diagnostic criteria. Revista Latinoamericana de Hipertensión 9: 20-31.

54. [No authors listed] (2016) Standards of Medical Care in Diabetes-2016: Summary of Revisions. Diabetes Care 39 Suppl 1: S4-5. 